\title{
Comparative amino acid requirements
}

\author{
By R. H. Sмгтн, National Institute for Research in Dairying, Shinfield, Reading \\ $R G_{2} g A T$
}

It is proposed to look, not at absolute requirements, but rather at the optimum pattern of essential amino acids (EAA) needed and the optimum value for the ratio EAA:total useful crude protein supply (CP; $N \times 6.25)$ when the supply is adequate but not excessive.

For monogastric mammals and poultry it is clearly of practical value to try to assess requirements in the diet. However, results may vary greatly (Hegsted, 1973; Bodwell, I 977) and for the ruminant they are valueless because of profound modification of AA supply in the reticulo-rumen. A more useful site for comparing requirements is the small intestine, particularly if available (i.e. absorbed) AA are considered.

Estimates of AA requirements for deposition in tissues, secretions or products provide fairly solid ground for making comparative assessments and it is plausible to suppose that they are related to requirements in the small intestine or the diet (Munks et al. 1945; Williams et al. 1954; Hutton \& Annison, 1972; Buraczewski, 1973; Hurwitz et al. 1978). However, for reliable predictions it is necessary to understand the ways in which AA are transported and metabolized between the gut and their final destination. In this paper, present knowledge of these processes and the possibilities of using factorial methods to try to identify differences in EAA requirements for a number of different species and physiological states are examined in Table 2.

EAA include leucine (Leu), isoleucine (Ile), valine (Val), methionine (Met), phenyl alanine (Phe), threonine (Thr), lysine (Lys), tryptophan (Trp) and histidine (His). In addition consideration is given to total sulphur-containing amino acids (S-AA; Met and Lys) and to total aromatic amino acids (Ar-AA; Tyr and Phe). Histidine is included although apparently not essential for adult man (Irwin \& Hegsted, 1971).

An excellent review of qualitative and quantitative comparative AA requirements for a variety of animals has recently been published (Buttery, 1979).

\section{Net requirements of EAA at 'deposition' level}

The main $\mathrm{N}$-containing body components are non-collagenous cells, collagen and keratin. As the relative proportions of these vary, for example collagen content increases with age (Widdowson \& Dickerson, 1960) concomitant variations in whole-body EAA composition can be expected. Such differences with age, have been reported (Burazewski, I973) but were small. Most workers have failed to detect consistent variation (Price et al. 1953; Williams et al. 1954; Davies \& 


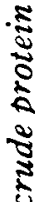

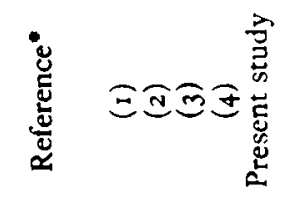

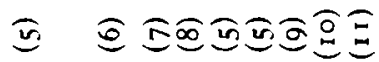

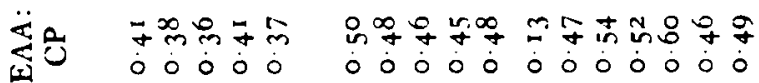

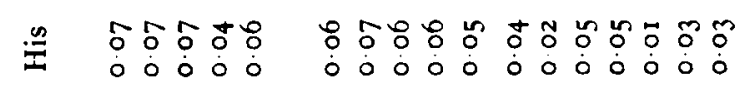

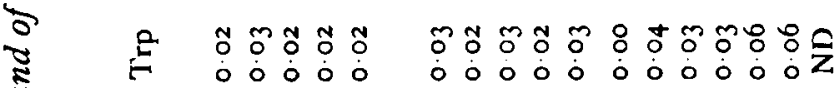

胥

$\$$

命

$\ddot{0}$

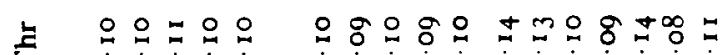

s

F ó்

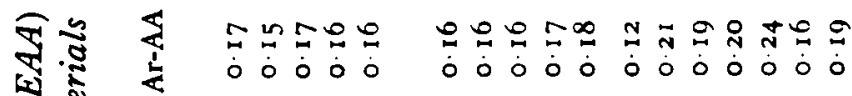

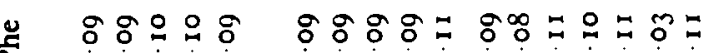

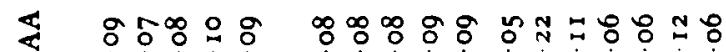

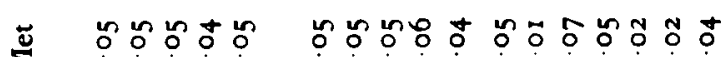

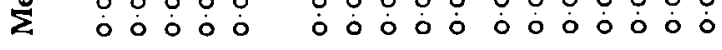

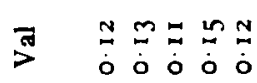

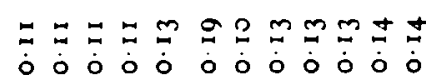

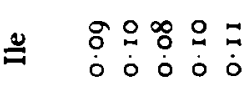
$Z=Z$ I

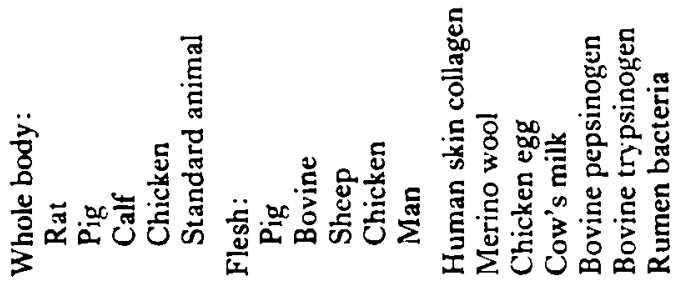


Thomas, 1975; Hurwitz et al. 1978) and there is not much variation between different species (Table I). Whole-body AA analyses are not available for man or sheep and to test whether they may be assessed from body component compositions a 'standard animal' was assumed with $\mathbf{N}$ provided by cellular protein $(66 \%)$, collagen $(30 \%)$ and keratin $(4 \%)$, the proportions were based upon average findings for collagen contents of different animals (Widdowson \& Dickerson, r 960; Picou et al. 1966; Williams, 1978) and keratin values for rat and chicken (Davies \& Thomas, 1975; Hurwitz et al. 1978). Composition of cellular protein was assumed to be given by a mean value for the flesh of sheep, cattle, pigs and chickens (Table 1). Variation between tissues exists (deVuyst et al. 1975) but is not sufficient for the generalized values for 'flesh' and 'offal' given in FAO (1970) to show consistent differences. Composition of collagen was taken as that of human skin collagen (Bornstein \& Piez, 1964) and of keratin as that of Merino wool (Simmonds, 1955). Keratin composition and amount will vary between species but, except in the sheep, its total contribution is too small for likely variations to have much effect.

The calculated whole-body composition of the 'standard animal' (Table I) is very similar to whole-body compositions of the rat, pig and calf and not very different from that for the chicken. It may be supposed that man also would correspond to the 'standard animal' if his cellular protein were similar in AA composition to that of the animal species used in the calculation. This appeared uncertain (Table I) particularly as the two sets of values used to derive mean human muscle composition were not in good agreement. However, in the studies of Müting \& Wortmann (1954) analyses of pig and rat as well as human muscle were reported and all were very similar. It has been concluded therefore that differences in analytical methods were responsible for the apparent discrepancies, that the generalized FAO (1970) values for animal muscle are also applicable to man and that the calculated 'standard animal' AA composition defines the EAA composition of growth for man as well as the other animals.

Apart from demands for $A A$ for synthesis of different products and digestive secretions (Table I) AA are needed to replace tissue protein lost in the course of protein turnover (Waterlow et al. 1978).

\section{Relations between net EAA requirements and absorbed requirements}

There are only a few published measurements directly relating disappearance of AA from the gut with their appearance in portal blood (Tagari \& Bergman, 1978) although studies of portal to hepatic vein differences and arterial to venous differences in AA flow across gut, liver, muscle and kidney in the rat, dog, man and sheep have been made, (e.g. Felig, 1975; Bergman \& Heitmann, 1978). Most studies have been of gluconeogenesis and methods of transporting energy sources or waste $\mathbf{N}$ about the body, and provide little quantitative information suitable for assessing relative efficiencies of EAA utilization. It appears that the liver removes most EAA which leave the gut (and presumably releases them later) by shifts in the balance of liver protein turnover but that some of the most abundant non-EAA are 
much more extensively metabolized. This indication that, as a group EAA are conserved relatively effectively receives strong support and a quantitative basis from the observations of Aguilar et al. (1972) who recovered smaller proportions of ${ }^{14} \mathrm{CO}_{2}$ when labelled EAA were given to rapidly growing rats than when labelled total AA were given. For the present calculation it has been assumed generally that EAA are used with $25 \%$ greater efficiency than non-EAA. The results of Aguilar et al. (1972) also showed that when different labelled EAA were given, methionine was oxidized to a greater extent than the others. The possibility of a relative inefficiency in the use of methionine was also postulated by Williams et al. (1954) and received support from the observations of Buraczewski (1973) for the pig. It has been assumed that methionine is used with $75 \%$ of the efficiency of other EAA for protein synthesis.

Although most EAA are approximately in balance across the mammary gland there is a marked loss of the branched-chain essential amino acids (BC-AA) and evidence that the products may be used for non-EAA synthesis (Clark et al. 1978). It has been assumed that BC-AA are used with $75 \%$ of the efficiency of other EAA for milk protein synthesis.

For the mature animal it is particularly important to know EAA requirement for tissue maintenance. Protein turnover requires a substantial and continuing supply of AA whether the animal is growing or not. The requirement is generally much greater than that needed for growth and considerably exceeds that supplied by the diet. The difference is made up by the reuse of AA liberated by protein catabolism (Waterlow et al. 1978). Endogenous urinary $\mathrm{N}$ excretion provides a measure of over-all inefficiency of that reuse but there is very little information on individual AA. Reported values for the dietary EAA pattern required at maintenance are very variable both for rat and man (Fisher et al. 1977) and do not provide any evidence for the maintenance EAA pattern being different from that of the tissue being maintained. However, EAA:CP values needed in the diet decline greatly (from about 0.35 to 0.15 ) from infancy to maturity in man (FAO/WHO, 1973) and a similar change can be seen in the rat (Bodwell, 1977). Now to simply replace tissue lost during turnover would require an EAA:CP value of about 0.45 so it appears that EAA must be conserved much more effectively than non-EAA during body tissue maintenance (el Lozy \& Hegsted, 1975). To explain the results in terms of the present calculations it is necessary to assume that the proportion of EAA lost during tissue maintenance in mature man is about $25 \%$ of the corresponding loss of CP. This relationship, also indicated for the rat, has been assumed to be general.

The other principal maintenance component is due to the loss of that part of the endogenous protein secretion into the alimentary tract that is not reabsorbed. The material lost has been assumed to possess the AA composition obtained by averaging those of bovine pepsinogen and trypsinogen (Table I).

\section{Requirements for absorbed EAA}

Examples are shown in Table 3 and Fig. I of calculated requirements based upon the assumptions described in the preceding section for animals characterized 
Table 2. Crude protein $(C P)$ requirements during growth and maturity for different species

\begin{tabular}{|c|c|c|c|c|}
\hline Animal & Body-wt (kg) & $\begin{array}{c}\text { Net CP } \\
\text { deposited }(g / d)\end{array}$ & $\begin{array}{c}\text { Tissue } \\
\text { maintenance } \\
(\mathrm{g} / \mathrm{d})\end{array}$ & $\begin{array}{l}\text { Intestinal } \\
\text { secretion } \\
\text { maintenance } \\
(\mathrm{g} / \mathrm{d})\end{array}$ \\
\hline Lactating cow & 600 & $900^{\circ}$ & 80 & 230 \\
\hline Laying hen & 2 & $6 t$ & $1 \cdot 2$ & 0.3 \\
\hline Growing rat & 0.12 & 0.72 & 0.09 & 0.18 \\
\hline Mature sheep & 50 & rof & 9.8 & $7 \cdot 5$ \\
\hline Human infant & 5 & 3.6 & 0.88 & 0.44 \\
\hline Growing calf & 50 & $37 \cdot 5$ & $21 \cdot 7$ & $9 \cdot 4$ \\
\hline Growing pig & 50 & 100 & 13.6 & 3.9 \\
\hline \multirow[t]{4}{*}{ Mature man } & 70 & 0 & 14.8 & 42 \\
\hline & & 'Milk. & & \\
\hline & & †Egg. & & \\
\hline & & $\ddagger$ Wool. & & \\
\hline
\end{tabular}

in Table 2. Maintenance requirements were calculated from information provided by Carr et al. (1977) for the pig, Boorman (1976) and Mitchell (1962) for the chicken, FAO/WHO (1973) for man, Williams et al. (1974) for the rat and ARC (1965) for the ruminant but a value of $2 \mathrm{~g} / \mathrm{kg}$ feed intake for calculating ruminant metabolic faecal $\mathrm{N}$ was used.

It is recognized that the results are dependent upon the assumptions made and that these are of varying reliability. Well-based assumptions determine that the growing animals show a fairly uniform requirement for most EAA, but with some differences for lysine, and that most groups have similar requirements for BC-AA. A high apparent need for BC-AA by the lactating cow stems from the more questionable assumption of their poor efficiency of utilization in milk synthesis and has not been tested in practice. The high apparent isoleucine requirement in man is due to a relatively high concentration in digestive secretions. Requirements for methionine and S-AA deposition vary widely due to differences in product composition and S-AA needs are very high for the sheep; a finding well supported in practice (Reis \& Schinckel, 1963). The lactating cow is shown to require relatively little S-AA and is unlikely to be specifically deficient in this respect. For the growing calf on the other hand, a comparison of EAA requirements with the composition of rumen microbial protein shows S-AA likely to be limiting and this is found in practice (e.g. Williams \& Smith, 1974). Requirements for phenylalanine deposition do not differ greatly among the groups but, because of wool composition, the sheep appears to have high Ar-AA requirements. For the same reason lysine requirements for the sheep are shown to be low and it is difficult to envisage a specific lysine deficiency normally occurring in this animal.

It is encouraging to find a close correspondence between the calculated EAA pattern for the growing pig (Table 3 ) and a requirement pattern recently derived 
Table 3. Individual essential amino acids $(E A A)$ required by different animals as proportions $(\mathrm{g} / \mathrm{g})$ of total $E A A$ required*

$\begin{array}{lccccccccccc} & \text { Leu } & \text { Ile } & \text { Val } & \text { Met } & \text { S-AA } & \text { Phe } & \text { Ar-AA } & \text { Thr } & \text { Lys } & \text { Trp } & \text { His } † \\ \text { Lactating cow } & 0.20 & 0.13 & 0.14 & 0.05 & 0.07 & 0.09 & 0.18 & 0.09 & 0.12 & 0.03 & 0.04 \\ \text { Laying hen } & 0.15 & 0.12 & 0.13 & 0.08 & 0.13 & 0.10 & 0.18 & 0.10 & 0.13 & 0.03 & 0.04 \\ \text { Growing rat } & 0.16 & 0.12 & 0.12 & 0.06 & 0.09 & 0.10 & 0.19 & 0.11 & 0.14 & 0.03 & 0.04 \\ \text { Mature shepp } & 0.15 & 0.12 & 0.11 & 0.03 & 0.14 & 0.09 & 0.22 & 0.13 & 0.07 & 0.04 & 0.02 \\ \text { Human infant } & 0.17 & 0.11 & 0.12 & 0.06 & 0.10 & 0.09 & 0.17 & 0.11 & 0.16 & 0.03 & 0.05 \\ \text { Growing pig } & 0.16 & 0.11 & 0.12 & 0.07 & 0.10 & 0.09 & 0.16 & 0.10 & 0.17 & 0.03 & 0.05 \\ \text { Growing calf } & 0.16 & 0.12 & 0.12 & 0.06 & 0.09 & 0.09 & 0.18 & 0.11 & 0.15 & 0.03 & 0.05 \\ \text { Mature man } & 0.15 & 0.14 & 0.12 & 0.04 & 0.09 & 0.08 & 0.18 & 0.10 & 0.13 & 0.04 & 0.04\end{array}$

-Estimated as described on p. 74.

†Assuming no synthesis of histidine.

experimentally by A. G. Low (personal communication) (Leu, $0 \cdot 16$; Ile 0.10 ; Val, 0.1 I; S-AA, 0.10; Ar-AA 0.19; Thr, 0.10; Lys, 0.18; Trp, 0.02 and His, 0.06. These, like subsequent values quoted for comparison have been recalculated as individual EAA :total EAA) but some earlier estimates (e.g. Buraczewski, 1973) show marked discrepancies. The calculated EAA pattern for the growing rat is closely similar to that in egg protein, long regarded as being nearly ideal for this species. It is also, except for showing a relatively low value for lysine, within the range of experimentally determined values quoted by Hegsted (1973) although these vary markedly. Apart from the high S-AA requirements of sheep little empirical information is available on the EAA pattern needed by ruminants. However, the observed S-AA:lysine value $\left(0.5^{8}\right)$ required for the calf (Williams \& Hewitt, 1979) is close to the present calculated value. The only experimentally determined EAA pattern requirements for the laying hen given in ARC (1975) are; Ile, 0.13 ; Met, 0.08 ; Lys, 0.17; Trp, 0.04. Agreement with calculated values is fairly good except for the latter giving a lower value for lysine.

Values for EAA pattern needed by the human infant proposed by $\mathrm{FAO} /$ WHO (1973) (Leu, 0.2 I; Ile, 0.09; Val, 0. I3; S-AA, 0.08; Ar-AA, 0. I 7; Thr, 0. I2; Lys, 0.14 ; $\operatorname{Trp}, 0.02$; His, 0.04 ) are similar to the present calculated pattern. Agreement of the calculated values with patterns proposed for mature man (e.g. $\mathrm{FAO}$ /WHO, 1973) is, however, poor. In particular, calculation suggests lower S-AA needs, a finding with some practical support (Williams et al. 1974) but it also probably underestimates lysine requirements.

Marked differences are shown in Fig. I between calculated EAA:CP requirements. It has been pointed out (el Lozy \& Hegsted, 1975) that a fall in this value with age in man implies a decreasing dependence upon high quality protein although whether this always occurs in practice has been questioned (Young et al. 1977). Similar reasoning suggests that protein quality would be of the utmost importance for the laying hen and lactating cow.

It should be stressed that conclusions from the present calculations are for absorbed AA. Relationships between absorbed and dietary requirements depend upon many modifying factors such as microbial involvement either directly or by 


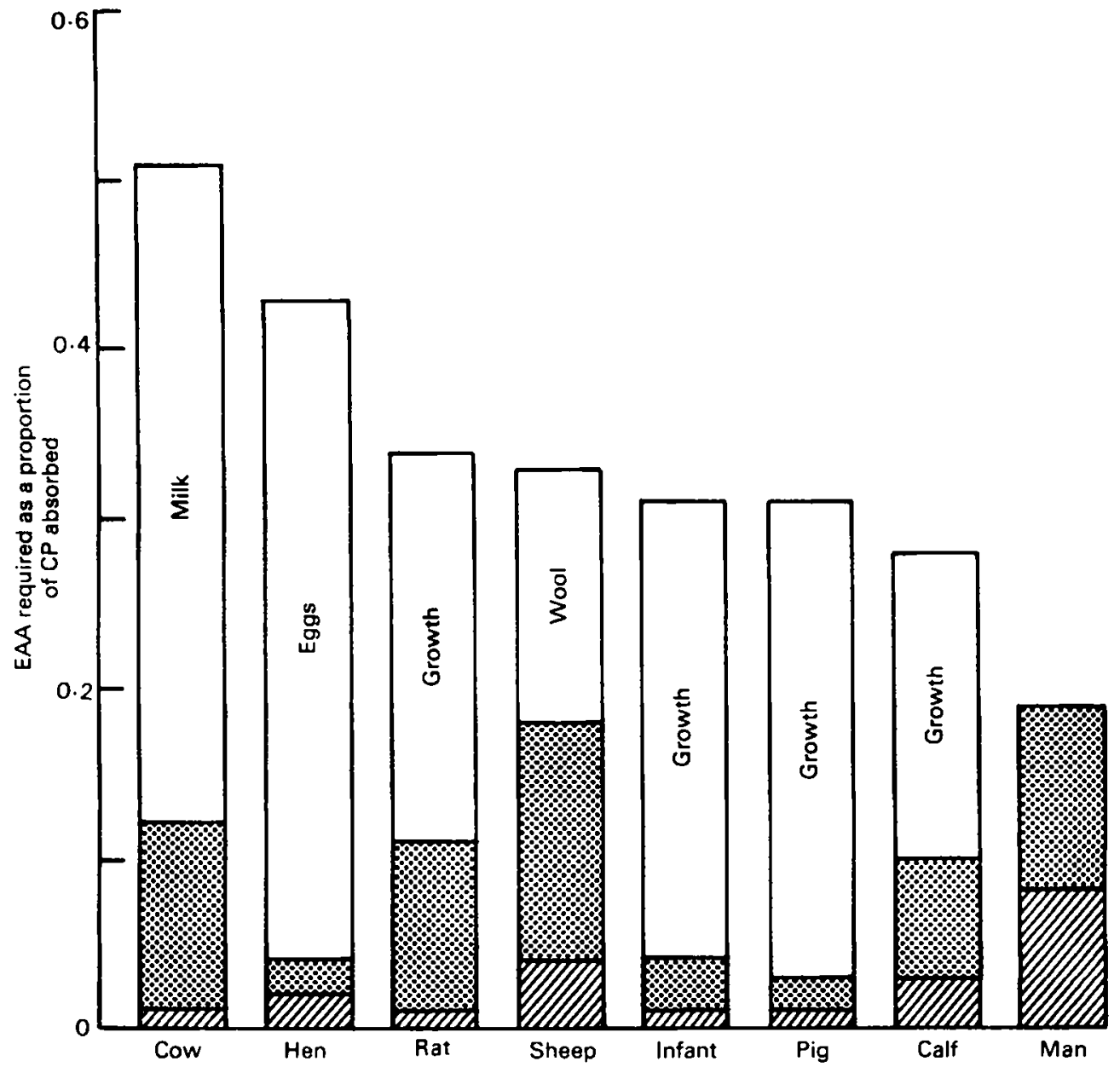

Fig. I. Optimum proportions $(\mathrm{g} / \mathrm{g})$ of total essential amino acids (EAA) in crude protein (CP) absorbed from the gut of different animals (total column heights) and the relative amounts of EAA used for growth or production ( $\square$ ), digestive secretions not reabsorbed ( WWM ) and tissue maintenance ( שIIJ). Estimated as described in the text.

coprophagy and differing digestibilities. Lysine, for example, is often relatively unavailable (Carpenter, 1974) so that dietary requirements would tend to be increased compared to other EAA.

The author thanks Dr A. P. Williams for bringing some of the more obscure information to his attention.

\section{REFERENCES}

Agricultural Research Council (1965). The Nutrient Requirements of Farm Lizestock, No. 2, Ruminants. London: HM Stationery Office.

Agricultural Research Council (1975). The Nutrient Requirements of Farm Livestock, No. I, Poultry. London: HM Stationery Office.

Aguilar, T. S., Harper, A. E. \& Benevenga, N. J. (1972). F. Nutr. 102, 199. 
Bergman, E. N. \& Heitmann, R. N. (1978). Fedn Proc. Fedn Am. Socs exp. Biol. 37, 1228.

Bocobo, D. I., Skelenger, M., Shaw, C. R. \& Steele, B. F. (1952). Archs Biochem. Biophys. 40, 448.

Bodwell, C. E. (1977). Cereal Chem. 54, $95^{8}$.

Boorman, K. N. (1976). In Digestion in the Fowl, p. 27, [K. N. Boorman and B. M. Freeman, editors]. British Poultry Science Ltd, Symposium No. I I.

Bornstein, P. \& Piez, K. A. (1964). F. clin. Invest. 43, 1813.

Buraczewski, S. (1973). Proc. Symp. Amino Acids, Brno, Czeckoslovakia, C. I.

Buttery, P. J. (1979). In Comparative Animal Nutrition, Vol. 3, p. 34, [M. Rechcigl, editor]. Basel: S. Karger.

Carpenter, K. J. (1974). Proc. Nutr. Conf. Feed Mfrs, University of Nottingham. 8, 71.

Carr, J. R., Boorman, K. N. \& Cole, D. J. A. (1977). Br. F. Nutr. 37, 143.

Chow, R. B. \& Kassell, B. (1968). F. biol. Chem. 243, 1718.

Clark, J. H., Spires, H. R. \& Davis, C. L. (1978). Fedn Proc. Fedn Am. Socs exp. Biol. 37, 233.

Davies, M. G. \& Thomas, A. J. (1975). Nutr. Rep. int. 11, 3.

deVuyst, A., Vervack, W., Vanbelle, M. \& Foulon, M. (1975). Rezue Ferment. Ind. aliment. 30, 37.

el Lozy, M. \& Hegsted, D. M. (1975). Am. F. clin. Nutr. 28, 1052.

Felig, P. (1975). A. Rer. Biochem. 44, 933 .

Fisher, H., Griminger, P. \& Brush, M. K. (1977). Am. Y. clin. Nutr. 30, 932.

Food and Agriculture Organization (1970). Amino Acid Content of Foods, FAO Nutr. Stud. No. 24 .

Food and Agriculture Organization/World Health Organization (1973). Energy and Protein Requirements, FAO Nutr. Mtg Rep. Ser. No. 52.

Hegsted, D. M. (1 973). In Proteins in Human Nutrition, p. 275, [J. W. G. Porter and B. A. Rolls, editors]. London: Academic Press.

Hurwitz, S., Sklan, D. \& Bartov, I. (1978). Poult. Sci. 57, 197.

Hutton, K. \& Annison, E. F. (1972). Proc. Nutr. Soc. 31, I 5 I.

Irwin, M. I. \& Hegsted, D. M. (1971). F. Nutr. 101, 539.

Mikes, O., Holeysovsky, V., Tomasek, V. \& Sorm, F. (1966). Biochem. biophys Res. Commun. 24, 346.

Mitchell, H. H. (1962). Comparatize Nutrition of Man and Domestic Animals, vol. I. New York: Academic Press.

Munks, B., Robinson, A., Beach, E. F. \& Williams, H. H. (1 945). Poult. Sci. 24, 459.

Müting, D. \& Wortmann, V. (1954). Biochem. Z. 325, 448.

Pellett, P. L. \& Kaba, H. (1972). F. Nutr. 102, 61.

Picou, D., Halliday, D. \& Garrow, J. S. (1966). Clin. Sci. 30, 345.

Price, W. A., Taylor, M. W. \& Russell, W. C. (1953). F. Nutr. 5I, $4 \mathrm{I} 3$.

Reis, P. J. \& Schinckel, P. G. (1963). Aust. F. biol. Sci. 16, 218.

Simmonds, D. H. (1955). Aust. F. biol. Sci. 8, 537.

Tagari, H. \& Bergman, E. N. (1978). F. Nutr. $1>8,790$.

Waterlow, J. C., Garlick, P. J. \& Milward, D. J. (1978). Protein Turnover in Mammalian Tissues and in the Whole Body. Amsterdam: North Holland Publishing Co.

Widdowson, E. M. \& Dickerson, J. W. T. (1960). Biochem. $\mathcal{~ Y . ~ 7 7 , ~} 30$.

Williams, A. P. (1978). Y. agric, Sci., Camb. 90, 61 7.

Williams, A. P. \& Hewitt, D. (1979). Br. F. Nutr. 41, 3 I I.

Williams, A. P. \& Smith, R. H. (I974). Br. Y. Nutr. 32, 42 I.

Williams, H. H., Curtin, L. V., Abaham, J., Loosli, J. K. \& Maynard, L. A. (I954). F. biol. Chem. $208,277$.

Williams, H. H., Harper, A. E., Hegsted, D. M., Arroyave, G. \& Holt, L. E. (1974). In Impronement of Protein Nutritize, p. 23. Washington DC: National Academy of Sciences.

Williams, P. P. \& Dinusson, W. E. (1973). Y. Anim. Sci. 36, 151 .

Young, V. R., Rand, W. M. \& Scrimshaw, N. S. (1977). Cereal Chem. 54, 929. 